\title{
Government Contract Bid Protests: Judicial Review and the Role of the Court of Claims
}

Each year the federal government awards contracts worth billions of dollars to obtain needed goods and services. ${ }^{1}$ In fiscal 1970, payments under these contracts amounted to more than one-half of all federal expenditures $^{2}$ and, together with procurements by state and local governments, accounted for roughly 23 percent of the gross national product. ${ }^{3}$ Procurement of goods and services by federal agencies is governed by an extensive set of statutes and regulations. ${ }^{4}$ Because of the complexity of the procurement system and the vital economic interests that it affects, there are occasional disputes between government contract officers and disappointed bidders concerning the precise requirements of these statutes and regulations and the factual situations to which they must be applied. ${ }^{5}$ Until recently, bidders who believed that government officers had somehow violated or misapplied applicable statutory or regulatory provisions in awarding contracts to their competitors could submit their claims to only two fora: the Comptroller General and the Court of Claims. Each of these, however, affords only a limited measure of review and allows forms of relief that may, in many cases, be inadequate. ${ }^{6}$ Nonetheless, before 1970, federal courts other than the Court of Claims refused to review government contract disputes on the grounds that disappointed bidders had no legal right

$1 \$ 100.8$ billion was spent by the federal government in fiscal year 1970. U.S. DEF'T of Commerce, Statistical Abstract of the United States 374, table 574.

2 Id.

3 Id. at 306 , table 485 .

4 Among the many laws and regulations dealing wholly or in part with the procurement process, those most important to federal procurement in general are: Armed Services Procurement Act of 1947, 10 U.S.C. \$§ 2301-14 (1970); Federal Property and Administrative Services Act of 1949, 41 U.S.C. \$\$ 251-60 (1970); Armed Services Procurement Regulations, 32 C.F.R. pts. 1-39 (1972); and Federal Procurement Regulations, 41 C.F.R. $\S \S 1-1.000$ et seq. (1972). Other acts that concern procurement include the DavisBacon Act, 40 U.S.C. $\S 276$ (a) (1970); Contract Work Hours and Safety Standards Act of 1962, 40 U.S.C. \$§ 327-32 (1970); and the Walsh-Fealy Act, 41 U.S.C. $\$ \S 35-45$ (1970).

5 The Comptroller General hears seven hundred to one thousand cases annually that allege violations of procurement statutes and regulations. See Wheelabrator Corp. v. Chafee, 455 F.2d 1306, 1315 n.12 (D.C. Cir. 1971).

6 For a discussion of the review provided by the Comptroller General and by the Court of Claims, see text at notes $40-59$ infra. 
that had been violated and, hence, no standing to bring suit, and that an agency's action in awarding a contract was discretionary.?

In 1970, in Scanwell Laboratories v. Shaffer, ${ }^{8}$ the Court of Appeals for the District of Columbia Circuit abandoned this traditional refusal to intervene in the procurement process, holding that disappointed bidders for government contracts have standing to challenge agency contract bid decisions in the federal courts. Scanwell did not, however, define the bid protest cases in which review by the federal courts is appropriate, nor did it determine the scope of review that the courts must apply. While bidders' suits are finally permitted, these problems remain unresolved and, together with limitations that have thus far been placed on available relief, seem to have discouraged bid litigation. ${ }^{\circ}$

This comment discusses the government contract bidding process insofar as it is conducted by means of formal advertising rather than negotiation. It then outlines the administrative and judicial review presently available to disappointed bidders, with particular attention to the institutional and pragmatic difficulties confronted by the courts in their brief experience with review of bid protests.

7 Most of the decisions refusing review of government contracting procedures were based on lack of standing to sue. In Perkins v. Lukens Steel Co., 310 U.S. 113 (1940), the leading authority for this proposition, the Supreme Court held that prospective bidders did not have standing because no "legal right" had been violated. Id. at 125. Earlier cases had held that regulations governing contracting were for the protection of the government and the public, and not for the protection of those persons who seek to or do contract with the government, American Smelting \& Ref. Co. v. United States, 259 U.S. 75 (1922); United States v. New York \& Porto Rico S.S. Co., 239 U.S. 88 (1915); that government rejection of bids was discretionary and not reviewable, Champion Coated Paper Co. v. Joint Comm., 47 App. D.C. 141 (D.C. Cir. 1917); B.F. Cummins Co. v. Burleson, 40 App. D.C. 500 (D.C. Cir. 1913); O'Brien v. Carney, 6 F. Supp. 761 (D. Mass. 1934); that accepting or rejecting bids was discretionary, and mandamus would not lie to compel such action, Goldberg v. Daniels, 231 U.S. 218 (1913); that a disappointed bidder (for a municipal contract) lacked standing to sue, Colorado Paving Co. v. Murphy, 78 F. 28 (8th Cir. 1897), appeal dismissed, 166 U.S. 719 (1897); and that suit was barred by sovereign immunity, Wells v. Roper, 246 U.S. 335 (1918). For thirty years after the Supreme Court's decision in Perkins, courts held that disappointed bidders lacked standing. E.g., Edelman v. FHA, 382 F.2d 594 (2d Cir. 1967). For the history of nonreview of procurement problems, see Judge Tamm's opinion in Scanwell Laboratories, Inc. v. Shaffer, 424 F.2d 859 (D.C. Cir. 1970). See also Pierson, Standing to Seek Judicial Review of Government Contract Awards: Its Origins, Rationale and Effect on the Procurement Process, 12 B.C. IND. \& COM. L. REv. I (1970).

8424 F.2d 859 (D.C. Cir. 1970).

- In a six-month period, five bid cases in the District Court for the District of Columbia were dismissed on motion of the plaintiff or on stipulation by both parties. Tasker Indus. v. Seamans, Civil No. 3482-70 (D.D.C., Feb. 8, 1971); Minor v. Paine, Civil No. 2286-70 (D.D.C., Nov. 9, 1970); Law Bros. v. Resor, Civil No. 2137-70 (D.D.C., Sept. 17, 1970); Arvin Indus. v. Chafee, Civil No. 2314-70 (D.D.C., Aug. 10, 1970); Winston v. Kunzig, Civil No. 1894-70 (D.D.G., Aug. 7, 1970). 


\section{The Bidding System, the General Accounting Office, AND THE COURT OF Claims}

\section{A. Advertised Bid Procedures and Protests}

Although many government contracts are awarded by negotiation, ${ }^{10}$ advertised bidding is the method of procurement preferred by law; ;1 $^{11}$ a number of statutes and regulations direct government officials to use it whenever feasible..$^{12}$ Congress favors formal advertisement because, at least presumably, it maximizes competition for contract awards. ${ }^{13}$ The first step in the advertising process is the drafting and issuance of the invitation for bids. The requirements of the procuring agency are set forth as specifically as possible to ensure that goods of the requisite quality are obtained ${ }^{14}$ and that bidders are informed equally of the government's needs..$^{15}$ The invitation must state the time, place, and date for opening the sealed bids. ${ }^{16}$ It must be published, either by mailing invitations to bidders whose names appear on government-maintained lists of eligible bidders, ${ }^{17}$ by placing announcements in trade journals or newspapers, ${ }^{18}$ or by including a notice of the procurement

10 Negotiated procurements account for more than half of the dollar value of all federal procurements, Pierson, supra note 7, at 2; in 1964, they accounted for 85 percent of the dollar value of military procurements, SUBCoMm. ON FEDERAL Procurement aNd REgulation of the Joint Economic Comm., 89th Cong., 1st Sess., Background Material on Economic Impact of Federal. Procurement 21 (1966).

1110 U.S.C. § 2304(a) (1970); 41 U.S.C. § 252(c) (1970).

12 See 32 C.F.R. § 1.300-2 (1972); 41 C.F.R. §§ 1-1.301-2, 1-2.102(a) (1972).

13 See Wheelabrator Corp. v. Chafee, 455 F.2d 1306, 1317 (D.C. Cir. 1971). Competition is maximized by allowing all companies capable of producing an item or providing a service to bid for the contract, and by guaranteeing equal knowledge of the government's needs to all bidders. See also 32 C.F.R. \$ 1.101 (1972); 41 G.F.R. \& 1-1.002 (1972).

14 R. Naser \& J. Gibinic, Federal Procurement Law 226 (1969). Professors Nash and Cibinic point out that, wherever there is leeway in the specifics, bidders will offer the lowest quality possible within the specifications since award is based primarily on price.

15 The preparation of an invitation of the requisite specificity is relatively simple for items of common usage and relatively difficult for complex or novel items. Cf. 32 C.F.R. $\S 2.201$ (1972); 41 C.F.R. § 1-2.201 (1972).

1641 U.S.C. § 253 (1970); 32 C.F.R. § 2.201 (1972); 41 C.F.R. § 1-2.201 (1972). The date set must allow a sufficiently long time for companies to prepare bids. 32 C.F.R. § 2.202-I (1972); 41 G.F.R. § 1-2.202-I(a) (1972); J. PAUL, UNITEd STATES GoverNMENT CoNTracts AND SUBCONTRACTs 150 (1964). The time and cost of bid preparation varies greatly, increasing with the complexity and novelty of the performance solicited. Cf. 41 C.F.R. \& 1-2.202-1 (b) (1972).

1732 G.F.R. $\S 2.203-1$ (1972); 41 C.F.R. § 1-2.203-1 (1972). Bidders may apply to have their names added to these bidder mailing lists, 32 C.F.R. $\$ 2.205-1(b)$ (1972); 41 G.F.R. \$ 1-2.205-1(b) (1972); and failure to respond to an invitation may result in removal of a bidder's name from the list, 32 C.F.R. \& 2.205-2(a) (1972); 41 C.F.R. \& I-2.205-2(a) (1972); R. NASH \& J. CrBinic, supra note 14, at 223; J. PAUL, supra note 16, at 149.

1832 C.F.R. § 2.203-3 (1972); 4 I C.F.R. § 1-2.203-3 (1972); R. NASH \& J. CiBINIC, supra note 14 , at 223 . 
in the Commerce Department's "Synopsis of United States Government Proposed Procurements, Sales and Contract Awards."10 Interested bidders must submit sealed bids to the contracting officer handling the procurement before the deadline announced in the invitation. ${ }^{20}$ At that time, the contracting officer opens all bids publicly ${ }^{21}$ and selects one for award.22

In making this selection, the contracting officer is required to make three determinations. First, he must conclude that the accepted bid is "most advantageous to the government, price and other factors considered." 23 Second, he must decide whether the bid is responsive to the advertised invitation, that is, whether it conforms to the specifications of the invitation in all material respects. ${ }^{24}$ Finally, the contracting officer must determine that the bidder receiving the award is "responsible": that he is capable of delivering the goods and services required in the prospective contract. ${ }^{25}$ To determine a firm's responsibility, the agency may conduct a preaward survey of its facilities, finances and experience, ${ }^{26}$ or, in the case of small businesses, the Small Business Administration may be asked to certify competence to meet contract requirements. ${ }^{27}$

Bid protests have often centered upon alleged error in the latter two determinations, those concerning the disappointed bidder's responsiveness to the invitation and his ability to fulfill the contract.

1932 C.F.R. § 2.203-4 (1972); 41 C.F.R. § 1-2.203-4 (1972); J. PAUL, supra note 16, at 150.

2032 C.F.R. $\$ 2.302$ (1972); 41 C.F.R. \& 1-2.302 (1972); see Simpson Elec. Co. v. Seamans, 317 F. Supp. 684 (D.D.C. 1970).

2110 U.S.C. § 2305 (c) (1970); 4 I U.S.C. § 253(b) (1970).

$22 \mathrm{Id}$. An agency may reject all bids rather than make an award when "the agency head determines that it is in the public interest to do so." Id.

23 Id.; 32 G.F.R. § 2.407-I (1972); 41 G.F.R. § 1-2.407.1 (1972).

2441 C.F.R. § 1-2.301(a) (1972) provides: "To be considered for award, a bid must comply in all material aspects with the invitation for bids so that, both as to the method and timeliness of submission and as to the substance of any resulting contract, all bidders may stand on an equal footing . . ." 4 I C.F.R. § 1-2.404-2(a) (1972) states: "Any bid which fails to conform to the essential requirements of the invitation for bids ... shall be rejected as non-responsive." Similar provisions are contained in 32 C.F.R. \$§ 2.301, 2.404-2 (1972).

2532 C.F.R. \& 1.904-1 (1972); 41 C.F.R. \& 1-1.1204-1(a) (1972). The integrity of the bidder is also a factor in responsibility. 32 C.F.R. $\$ 1.903-1$ (d) (1972); 41 C.F.R. $\$ 1-1.1203-1$ (d) (1972). This factor relates to the probable inclination of the bidder to perform as required instead of his capacity to do so.

2632 G.F.R. \& 1.905-4 (1972); J. PAUL, supra note 16, at 153.

27 32 C.F.R. § 1.705-4(a) (1972); 41 C.F.R. § 1-1.708-1 (1972). 39 CoMP. GEN. 868 (1960) holds that a certificate of competency from the Small Business Administration is binding upon the contracting officer. Contra, Warren Bros. Rds. Co. v. United States, $173 \mathrm{Ct}$. Cl. 714 (1965). The Comptroller General's decision seems more in conformity with 15 U.S.G. \& 637(b)(7) (1970). But see 32 C.F.R. \& 1.705-4(a), (f), (g) (1972); 41 C.F.R. \& 1-1.708-3 (1972). 
Bids may fail to be responsive to the invitation for any one of several reasons: if the bid invitation is ambiguous, the bidder's understanding of it may differ from that of the contracting officer; ${ }^{28}$ the bidder may make a mistake in the form of his submission by failing, for example, to sign the bid; ${ }^{29}$ the bidder may deviate from the invitation's requirements in what he considers a minor detail or may request an exemption from certain requirements; ${ }^{30}$ or, finally, the bidder may knowingly submit a bid that does not meet the standards set out in the invitation in the hope that his bid will be lowest and that he will, therefore, obtain the contract. ${ }^{31}$ Difficulties in applying the responsibility requirement and, hence, disputes concerning its application seem generally to have resulted from a lack in the statutes and regulations of any specific standards to guide the contracting officer in making this determination. The criteria of responsibility provided in the statutes and regulationsthat the successful bidder have "adequate financial resources" and a "satisfactory record of integrity, judgment and performance"32_necessarily require the contracting officer to make subjective, ad hoc judgments and lead to disputes as to whether the officer's notion of what is adequate or satisfactory is correct.

Another ground for protest commonly alleged by bidders is that a bid invitation was defective, either because it was ambiguous as to what product or service was desired or as to how the bids were to be eval-

28 A.G. Schoonmaker Co. v. Resor, 319 F. Supp. 933 (D.D.C. 1970), rev'd, 445 F.2d 726 (D.C. Cir. 1971).

29 Superior Oil Co. v. Udall, 409 F.2d 1115 (D.C. Cir. 1969). But see 32 G.F.R. § 2.405(c) (1972); 41 C.F.R. § 1-2.405(c) (1972). Bids have also been found nonconforming where the accompanying bond is insufficient. Cf. United States ex rel. Brookfield Constr. Co. v. Stewart, 234 F. Supp. 94 (D.D.C.), affd 339 F.2d 753 (D.C. Cir. 1964).

3034 COMP. GEN. 24 (1954); 30 CoMP. GEN. 179 (1950). The frequency of "minor" deviations from IFB specifications and of requests for permission to deviate from the invitation indicate that many government bidders believe they have some opportunity to bargain with the procuring agency. $R$. NASH \& J. CIBINIC, supra note 14, at 226; Shnitzer, Ambiguities in Invitations and Bids, 68 BRIEFING PApers No. 6, at 9 (1968). Where the deviation affects "price, quantity or quality of the articles offered," it cannot be waived. 30 COMP. GEN. 179 (1950). A request that causes a bid to be ambiguous may be a ground for rejection of the bid, even though it would be the low bid under any interpretation. Id. Contra, Shnitzer, supra, at 6. But see 32 C.F.R. § 2.404-2(d) (1972); 41 C.F.R. § 1-2.404-2 (b) (1972).

81 Prestex, Inc. v. United States, 320 F.2d 367 (Ct. Cl. 1963).

3232 C.F.R. § 1.903 (1972); 41 C.F.R. \& 1-1.1203-1 (1972). Complaints by bidders over determinations that they are not responsible, or that lower bidders are, seldom result in reversal of the contracting officer's decision. For example, the contracting officer's decision that a bidder who provided 80 percent of the helicopter services in a region was not qualified for a contract to furnish helicopter services in that region was sustained. 36 COMP. GEN. 42 (1956). 
uated,33 or because the invitation was overly restrictive, requiring, or seeming to require, inclusion in the bids of features unnecessary to the procurement. $^{34}$ In either case, if a bid invitation does not serve as an accurate guide for bidders, the agency may cancel it and readvertise the procurement. $^{35}$

Finally, there have frequently been allegations by disappointed bidders that either government officials or other bidders have engaged in fraud or other misconduct. Bidders have complained, for example, that contracting officials had let contracts to favored bidders after fraudulently rejecting lower bids; ${ }^{30}$ that other bidders had engaged in collusive bidding; ${ }^{37}$ and that other bidders had misled government officers by making false statements ${ }^{38}$ or by submitting the products of other companies as their own. ${ }^{39}$

\section{B. Bid Protest Fora: The General Accounting Office and the Court of Glaims}

Although contracting agencies have boards of contract appeals to consider disputes concerning contract terms, there are no similar administrative review boards to consider the kinds of bidders' protests described above. ${ }^{40}$ Prior to the Scanwell decision, therefore, the only

83 Shnitzer, supra note 30 . Although factors to be considered in evaluating bids cannot be stated precisely, they may be used. 43 CoMP. GEN. 663 (1964). Examples of such vague but relevant evaluation factors for lease of office space are: usefulness of space for good office layout; availability of transportation, parking, and eating facilities; and physical characteristics of the building and neighborhood. $I d$.

3444 Comp. Gen. 302 (1964); Bronson, The Sovereign in the Market-Place-A Panoramic View of Legal Peculiarities of Contracting with the Federal Government, 4 WAsHBURN L. REv. 45, 55 n.55 (1964).

3532 C.F.R. § 2.404-1(b)(1) (1972); 41 C.F.R. § 1-2.404-1(b)(1) (1972); 42 COMP. GEN. 257 (1962).

38 E.g., United States v. Gray Line Tours, 311 F.2d 779, 782-83 (4th Cir. 1962). Usually complaints of fraud arise when a number of lower bids are rejected and the contract awarded for a relatively high bid. In Heyer Prods. v. United States, 177 F. Supp. 251 (Ct. Cl. 1959), ten bids were submitted, and the lowest six were rejected. The bid accepted was nearly double that of the protesting company. Disappointed bidders may also complain that there is a tie between the company receiving the award and the government. In one case, a company operating an Atomic Energy Commission plant helped draft specifications for equipment to be added to the plant. The three lowest bids were rejected as nonresponsive, and the company that drafted the specifications received the award. 38 CONP. GEN. 59 (1958).

37 Lind v. Staats, 289 F. Supp. 182 (N.D. Cal. 1968); 39 Comp. GEN. 524 (1960).

38 Royal Servs., Inc. v. Maintenance, Inc., 361 F.2d 86 (5th Cir. 1966).

3939 COMP. GEN. 254 (1959).

40 Cibinic \& Lasken, The Comptroller General and Government Contracts, 38 Geo. WAsH. L. Rev. 349, 374 (1970). See also Levanthal, Public Contracts and Administrative Law, 52 A.B.A.J. 35, 39-40 (1966). 
fora open to disappointed bidders were the General Accounting Office and the Court of Claims.

1. Review by the General Accounting Office. The Comptroller General, who is the chief executive officer of the General Accounting Office (GAO), has no explicit statutory authority to review bidders' protests. ${ }^{41}$ The GAO, acting as an arm of Congress responsible for ensuring efficient operation of the government, ${ }^{42}$ must certify the accounts of disbursing officers; it may withhold approval of disbursements if they are made for improper purposes or pursuant to invalid contracts. ${ }^{43}$ The Budget and Accounting Act of 1921 gives disbursing officers, who are personally liable for improper expenditure of government funds, ${ }^{44}$ a right to decisions in advance by the Comptroller General concerning the legality of proposed payments. ${ }^{45}$ Although the statute extends the right of GAO review neither to bidders nor to contracting officers, the GAO has, since its inception, afforded review of bidders' protests and has rendered decisions on disputed matters when requested to do so by contracting officers.

Bidders may file protests with the Comptroller General alleging that the procuring agency has failed to comply with any of the applicable statutes or regulations. After receipt of a protest, the Comptroller solicits comments from the agency. ${ }^{46}$ Informal conferences are usually held whenever requested by either the bidder or contracting agency, and other bidders interested in the procurement in question are allowed to participate. ${ }^{47}$

Although review by the GAO may operate effectively as a check on inefficiencies that result from violations of bid regulations, it does not

41 Machinery and Allied Products Instrtute \& Council for Technological Advancement, The Government Contractor and the General Accounting Office 10 (1966) [hereinafter Machinery and Allied Products InstrTute]; Cibinic \& Lasken, supra note 40 , at 350 .

4231 U.S.C. $\$ \S 71,74$ (1970).

43 John Reiner \& Co. v. United States, 325 F.2d 438 (Ct. Gl. 1963), cert. denied, 377 U.S. 931 (1964). See generally MAchrnery AND ALlIEd ProdUcts INsTTTUTE, supra note 41; Birnbaum, Government Contracts: The Role of the Comptroller General, 42 A.B.A.J. 433 (1956); Cibinic \& Lasken, supra note 40; Owens, A Primer of Procurement by Formal Advertising and Relief for Mistakes in Bids, 42 N.Y. ST. B.J. 428 (1970); Shnitzer, Changing Concepts in Government Procurement-the Role and Influence of the Comptroller General on Contracting Officer's Operation, 23 FED. B.J. 90 (1963); Witte, Protesting the Award of Government Contracts, 12 PRAC. LAw., Mar., 1966, at 60.

44 Cibinic \& Lasken, supra note 40 , at 358.

4531 U.S.C. $\$ 74$ (1970). Another provision for advance GAO decisions to disbursing officers was included in the Disbursing and Certifying Officers Act of 1941, 31 U.S.C. $§$ 82(d) (1970).

46 Cibinic \& Lasken, supra note 40, at 374-75; Witte, supra note 43.

47 Cibinic \& Lasken, supra note 40, at 374-75. 
guarantee to bidders administrative compliance with procurement law. Unlike federal agencies that regulate labor relations, communications, commerce, and securities, the GAO was not designed to be a forum for the resolution of competing interests. It was, instead, intended primarily to perform investigative and auditing functions, ${ }^{48}$ and the only interest it is mandated to serve is the public interest in efficient government. Perhaps because of this limited mission, the GAO has failed to provide procedures adequate to protect the interests of disappointed bidders. It makes no provision in bid protest cases for formal hearings with opportunities for interested parties to present evidence and oral argument concerning the alleged violations. Instead, absent "convincing evidence" to the contrary, the GAO accepts as true the facts contained in the comments it solicits from the procuring agency. ${ }^{49}$

The limited mission of the GAO is also reflected in the restricted nature of the remedies granted by the Comptroller and in his reluctance to grant relief even when a bidder's protest is meritorious. If the Comptroller finds that a violation of bid regulations has occurred, he may direct that the procurement be cancelled and readvertised or that certain bids be rejected or reconsidered. ${ }^{50}$ The Comptroller does not, however, order agencies to award contracts to bidders who would have received them had the applicable regulations been followed; nor can he award damages. Even the limited remedy of contract cancellation may be withheld if work on the contract has proceeded so far that cancellation would be inefficient. ${ }^{51}$ The GAO's reluctance to reverse agency

48 Machinery and Allied Products Institute, supra note 41, at 17-33.

4942 Comp. Gen. 126, 134 (1962); Machinery and Allied Products Institute, supra note 41, at 58; Cibinic \& Lasken, supra note 40 , at 374 .

50 Cibinic \& Lasken, supra note 40 , at 374 . There is some dispute as to the binding nature of the Comptroller General's decisions. Compare John Reiner \& Co. v. United States, 325 F.2d 438 (Ct. Cl. 1963), cert. denied, 377 U.S. 931 (1964); MACHINERY AND ALLIED Products InstituTe, supra note 41; Cibinic \& Lasken, supra note 40 with Shnitzer, supra note 43 and Welch, The General Accounting Office in Government Procurement, 14 FED. B.J. 321 (1954). But executive agencies uniformly comply with his directives.

51 Machinery and Allied Products Instrtute, supra note 41, at 49; J. PaUt, supta note 16, at 159-60; Owens, supra note 43, at 428; Witte, supra note 43, at 64. See generally Cibinic \& Lasken, supra note 40. In fiscal year 1971, the Comptroller General rendered 715 formal decisions in bid protest cases, of which 641 protests were denied and 74 were sustained. Only in four cases did the Comptroller recommend contract cancellation. Address by Paul G. Dembling, General Counsel, General Accounting Office, before the National Contract Management Association, Washington, D.C., Sept., 1971, cited in Wheelabrator Corp. v. Chafee, 455 F.2d 1306, 1314 n.10 (D.C. Cir. 1971). Even where there was an uncontested claim that another bidder received a contract award due to fraud, the Comptroller General has refused to recommend cancellation. 39 CoMr. GEN. 254 (1959). But see 34 CoMp. GEN. 82, 84 (1954): "The strict maintenance of the competitive bidding procedures required by law is infinitely more in the public interest than ob- 
action is illustrated by one case in which, of three bids submitted, only two were accompanied by product samples that met the specifications contained in the invitation for bids. The contract was awarded to the firm that had made the lower of the two responsive bids. The other responsive bidder protested, claiming that the sample submitted by the successful bidder was, in fact, the protesting company's product. This assertion was not disputed, but the Comptroller General, nonetheless, upheld the award, stating that, although the contractor's action would have constituted an unfair business practice had it occurred in interstate commerce, it was permissible in bidding for government contracts. ${ }^{52}$

2. Review by the Court of Claims. In 1956, when other federal courts refused to entertain any action protesting government contract awards, the Court of Glaims, which has jurisdiction over nontort damage suits against the federal government, ${ }^{53}$ extended review to one type of bidder's suit. In Heyer Products $v$. United States, ${ }^{54}$ the court held that unsuccessful bidders could recover bid preparation expenses if they could demonstrate that bids were invited in bad faith after contracting officers had already decided which firm would receive the contract. The relief promised by Heyer Products has remained, however, a matter of potential since neither in that case nor in any subsequent case has a bidder been able to establish that government officers invited bids in bad faith. ${ }^{55}$ Nonetheless, following the decision in Scanwell, ${ }^{\text {b6 }}$ the Court of Claims extended its review to bid protests alleging arbitrary actions other than the narrow bad faith invitation of Heyer Products. ${ }^{57}$ The decision to extend review to these additional cases was announced in Keco Industries, Inc. v. United States. ${ }^{58}$ At the same time, however, the court stated that bidders could only receive damage awards limited to reimbursement for bid preparation costs. ${ }^{59}$

taining a pecuniary advantage in individual cases by permitting practices which do violence to the spirit and purpose of the law."

5239 COMP. GEN. 254, 256-57 (1959).

ธ3 28 U.S.G. § 1491 (1970).

54140 F. Supp. 409 (Ct. C1. 1956).

55 Robert F. Simmons \& Assocs. v. United States, 360 F.2d 962 (Ct. Cl. 1966); Trans Int'l Airlines, Inc. v. United States, 351 F.2d 1001 (Ct. Gl. 1965); Green Manor Constr. Co. v. United States, 169 Ct. Cl. 413 (1965); Iscrow v. United States, 161 Ct. Cl. 875 (1963); Locke v. United States, 283 F.2d 521 (Ct. Cl. 1960); Keco Indus., Inc. v. United States, 149 Ct. Cl. 837 (1960), cert. denied, 365 U.S. 815 (1961); Heyer Prods. Co. v. United States, 177 F. Supp. 251 (Ct. Cl. 1959).

56 Scanwell Laboratories, Inc. v. Shaffer, 424 F.2d 859 (D.C. Cir. 1970).

67 E.g., Chris Berg, Inc. v. United States, 426 F.2d 314 (Ct. Cl. 1970).

58428 F.2d 1233 (Ct. Cl. 1970).

59 Id. at 1240 . 


\section{Judicial Review}

\section{A. The Scanwell Laboratories Decision}

Despite the absence of formal administrative machinery to deal with bid disputes, the inadequacy of the Comptroller General's review to protect the interests of bidders, and the limitations placed upon the Court of Claims' review by the Heyer Products rule, until 1970 other federal courts refused to review government contract awards in actions brought by disappointed bidders. ${ }^{60}$ This refusal was based on the Supreme Court's decision in Perkins v. Lukens Steel Co., in which the Court held that prospective bidders had no legal rights injured by the promulgation of regulations that they claimed were illegal. ${ }^{61}$ Although the Supreme Court abandoned the legal right test for standing shortly after the Perkins decision, ${ }^{62}$ that case-and its dictum that awarding a contract was a discretionary act of government-was cited until the Scanwell Laboratories decision as precluding review of the legality of contract awards. ${ }^{63}$

Scanwell Laboratories was the culmination of a series of cases decided by the Court of Appeals for the District of Columbia Circuit that had, in effect, undermined the Perkins decision as authority for denying standing to disappointed bidders. ${ }^{64}$ In Scanwell, the court recognized the abandonment of the legal right test and found that the bidders'

Bo See cases cited note 7 supra.

61310 U.S. 113 (1940).

62 See Judge Tamm's discussion of the standing cases in Scanwell Laboratories, Inc. v. Shaffer, 424 F.2d 859 (D.C. Cir. 1970). See also Comment, Judicial Review of Agency Action: The Unsettled Law of Standing, 69 Mich. L. Rev. 540 (1971); Comment, Competitors' Standing to Challenge Administrative Action-Recent Federal Developments, 48 N.C.L. REv. 807 (1970).

63 Edelman v. FHA, 382 F.2d 594 (2d Cir. 1967); United States v. Gray Line Tours, 311 F.2d 779 (4th Cir. 1962); Friend v. Lee, 221 F.2d 96 (D.C. Cir. 1955); Fulton Iron Co. v. Larson, 171 F.2d 994 (D.C. Cir. 1948), cert. denied, 336 U.S. 903 (1949); Walter P. Villere Co. v. Blinn, 156 F.2d 914 (5th Cir. 1946); Lind v. Staats, 289 F. Supp. 182 (N.D. Cal. 1968). For cases precluding review on similar grounds, see Royal Servs., Inc. v. Maintenance, Inc., 361 F.2d 86 (5th Cir. 1966); and Szmodis v. Romney, 307 F. Supp. 607 (E.D. Pa. 1969).

64 See Air Reduction Co. v. Hickel, 420 F.2d 592 (D.C. Cir. 1969) (companies that do business with the government had standing to challenge regulations terminating their business relations); Superior Oil Co. v. Udall, 409 F.2d 1115 (D.C. Cir. 1969) (enjoining a government lease of land to the high bidder, found by the court to have been nonresponsive, and compelling lease to the plaintiff, second high bidder); Gonzales v. Freeman, 334 F.2d 570 (D.C. Cir. 1964) (contractor had standing to protest debarment); Copper Plumbing \& Heating Co. v. Campbell, 290 F.2d 368 (D.C. Cir. 1961) (contractor had standing to challenge an administrative regulation that would make him ineligible for government contracts for a three-year period); George v. Mitchell, 282 F.2d 486 (D.C. Cir. 1960) (contractor had standing to attack an administrative interpretation of the WalshHealy Act that debarred him from contract awards). 
standing to sue was supported by two interests: first, the interest of the bidder himself as a person allegedly harmed in fact by illegal, arbitrary, capricious action; and second, the interest of the public, represented by the bidder as a "private attorney general," in having government contracts awarded fairly and according to defined rules. ${ }^{65}$

B. Review after Scanwell: Bidders' Suits under the Administrative Procedure Act

Although Scanwell held that bidders have standing to bring actions for review of government contract awards, the court did not thereby hold that all federal contract decisions are necessarily subject to judicial review in suits brought by disappointed bidders; nor did it define the scope of review that the courts should apply. In short, Scanwell resolved only the threshold question of standing; and bid cases since Scanwell indicate that the courts remain uncertain not only as to what contract awards are subject to review and what scope of review is appropriate, but also as to the substantive criteria for determining whether injunctive relief is warranted. These issues-standing, reviewability, scope of review, and remedies-are analytically distinct. Nevertheless, the opinions in bid cases often seem to confuse them, perhaps because, in deciding them, the courts must take many of the same considerations into account.

The Administrative Procedure Act does not provide entirely clear standards for making these determinations. The section of the Act governing reviewability insulates agency actions from review "to the extent that (1) statutes preclude judicial review; or (2) agency action is committed to agency discretion by law." 66 This language allows the courts a considerable degree of latitude to determine the extent to which a statute expressly prohibiting review or declaring administrative action discretionary should operate to make an agency action unreviewable. Courts have, for example, agreed to inspect the rationality of discretionary determinations in procurement ${ }^{67}$ and other fields, ${ }^{68}$ and have indicated willingness to review allegedly fraudulent administrative decisions even where a statute clearly states that the kind of decision in question is not subject to review. ${ }^{69}$ At the same time, courts have in some cases declined to review agency actions even though they are not sheltered by the reviewability provisions of the Act and meet other constitutional and judicially created standards for review. ${ }^{70}$

65424 F.2d at $862-65,872-73$.

665 U.S.C. $\S 701$ (1970).

67 See Blackhawk Heating \& Plumbing Co. v. Driver, 433 F.2d 1137 (D.C. Cir. 1970).

68 E.g., Hintopoulos v. Shaughnessy, 353 U.S. 72 (1957).

69 See Wheelabrator Corp. v. Chafee, 455 F.2d 1306, 1311-12 (D.C. Cir. 1971).

70 Cf. Ludecke v. Watkins, 335 U.S. 160 (1948). 
The provisions in the Administrative Procedure Act that govern scope of review leave even more room for the exercise of judicial discretion than does the section governing reviewability. The Act appears to specify three different scopes of review, each applicable to a different type of administrative determination. First, when administrative actions are taken after hearings required either under the Act or another statute, the Act allows the courts to decide whether allegedly erroneous factual determinations are supported by substantial evidence on the record. ${ }^{71}$ If, therefore, an agency action may be taken without a hearing, courts may be precluded from reviewing factual decisions directly. Second, the Act states that the courts "shall decide all relevant questions of law."72 Thus, if the challenged agency action rests explicitly or implicitly on an interpretation of law, the reviewing court determines whether the agency interpretation is correct. This review of questions of law is qualified, however, by the Act's reviewability provision: ${ }^{73}$ where legal interpretation is entrusted to the agency, no direct review of the decision may be afforded. Finally, the Act states that the courts "shall ... hold unlawful ... agency actions, findings and conclusions found to be arbitrary, capricious, an abuse of discretion, or otherwise not in accordance with law."74 Under this provision, a reviewing court may set aside factual determinations, including those not subject to the substantial evidence test, and legal decisions, including those committed to agency discretion, if it finds that the administrator acted arbitrarily, without a rational basis.

The provisions of the Act, although complex, appear to define the scope of review appropriate to any challenge to administrative action. Some problems are evident, however, in the courts' application of the Act. First, an administrative determination may not fit neatly into any one of the categories defined by the Act, each with its appropriate scope of review. ${ }^{75}$ And second, the generalized language of the Act cannot take into account the competing interests that favor or oppose review in a particular case-interests that the courts may feel compelled to identify and weigh in determining the extent to which they should review agency action. As a result, courts may decide, first, whether the interests involved in a case militate for or against extensive review and then decide accordingly the appropriate scope of review to apply. Thus, when a court finds that, on balance, the interests weigh against broad review, it may hold that the action in question is discretionary and sub-

71 5 U.S.C. $\S 706(2)(E)(1970)$.

72 Id. \& 706.

73 Id. \$ 701.

74 Id. § 706(2)(A).

75 See K.C. Davis, 4 Administrative LaW Treatise \$ 30.01 (1958). 
ject only to the rational basis test, or that the issue is one of fact and can be reviewed only for substantial evidence, even if the action rested, explicitly or implicitly, on an interpretation of law.78

In bidders' suits, as in other cases involving judicial review of administrative actions, the courts' decisions as to reviewability and, particularly, scope of review seem often to turn upon their evaluation of the interests that these decisions will affect. The courts have recognized two sometimes competing interests involved in actions brought by disappointed bidders: the interest of both the bidder and the public in administrative fairness and the public interest in efficient operation of the government. The public interest in fairness and in compliance with announced rules reflects concern for control of the government's exercise of power. ${ }^{77}$ And the bidder is, of course, interested in fairness because failure, whether intentional or inadvertent, to award contracts fairly and according to prescribed standards subjects bidders who would otherwise have been successful to the loss of both bid preparation expenses and profits from the prospective contract. ${ }^{78}$

While courts have repeatedly noted the importance of these interests that favor broad review of contracting officers' decisions, they have generally found them outweighed by the public interest in efficient operation of the government. ${ }^{79}$ In the long run, the public interest in fairness and the interest in governmental efficiency are fully consistent since a fair system of contract awards increases the likelihood that the government will obtain needed goods and services at the lowest possible cost. Nonetheless, courts seem concerned, not with the general problem of efficient procurement, but rather with the inefficiencies that could result from extensive review of the particular contract awards before them.

The courts have focused, in particular, on the problems involved in substitution of judgment and the comparative competence of decision makers. ${ }^{80}$ Because of their inexperience with the factors that contracting

76 Cf. id. $\$ \S 30.01$ et seq.

77 See R. NASh \& J. Cibinic, supra note 14, at 221-22. See generally K.C. Davis, DrsGRetionary Justice: A Preliminary InQuiry (1969). The possibility of abuse is particularly great in an area such as government contracting where award of contracts worth large sums of money depends on determinations made by one or a few people. Concern over such possibilities led Congress as early as 1809 to enact legislation requiring open award of government contracts. Act of Mar. 3, 1809, 19 ANNALs of CoNGress 1833, 1835 (1809).

78 See text at notes $112-17$ infra.

79 See Allen M. Campbell Co. v. Lloyd Wood Constr. Co., 446 F.2d 261 (5th Cir. 1971); A.G. Schoonmaker Co. v. Resor, 445 F.2d 726 (D.C. Cir. 1971); M. Steinthal \& Co. v. Seamans, 455 F.2d 1289 (D.C. Cir. 1970); City Chem. Corp. v. Shreffler, 333 F. Supp. 46 (S.D.N.Y. 1971); Lombard Corp. v. Resor, 321 F. Supp. 687 (D.D.C. 1970).

80 The comparative qualifications of courts and agencies to make certain kinds of de- 
officers must consider in making awards, courts have, in some bid protest cases, afforded only limited review even as to questions that concern the interpretation of procurement statutes and regulations. ${ }^{81}$ Although judges are generally more competent than government administrators to interpret laws, ${ }^{82}$ the issues that bidders have presented for judicial review have depended, to a great extent, on highly specialized technical knowledge. The courts have been asked, for example, to define what constitutes responsiveness to a bid invitation in a particular case ${ }^{83}$ and to determine what degree of ambiguity in the invitation requires rejection of bids and readvertisement. ${ }^{84}$ The answers to these questions require detailed knowledge of the reasons for and significance of the bid's specifications and of the problems involved in producing the items for which the government proposes to contract. ${ }^{85}$ While it may be possible to adduce expert testimony on such technical matters so that the judge can make an informed decision, it is less expensive and time consuming for the court to defer to the greater competence of those who have already considered the case.

Courts have, therefore, generally been willing to defer to administrative expertise when an agency or official other than the original contracting officer has passed on the issue in dispute. ${ }^{86}$ They have accorded considerable respect to the decisions of the GAO and the Small Business Administration;87 since Scanwell, the decisions of these agencies in bid

cisions is one of three considerations that Professor Davis has concluded guide courts generally in choosing a scope of review of "application of law." R.C. Davrs, supra note 75, $\$ 30.09$.

81 E.g., M. Steinthal \& Co. v. Seamans, 455 F.2d 1289, 1301-02 (D.C. Cir. 1970); City Chem. Corp. v. Shreffler, 333 F. Supp. 46, 48 (S.D.N.Y. 1971).

82 K.C. Davis, supra note $75, \S 30.09$.

83 Lombard Corp. v. Resor, 321 F. Supp. 687 (D.D.C. 1970); Simpson Elec. Co. v. Seamans, 317 F. Supp. 684 (D.D.C. 1970).

84 M. Steinthal \& Co. v. Seamans, 455 F.2d 1289 (D.C. Cir. 1970); A.G. Schoonmaker Co. v. Resor, 319 F. Supp. 933 (D.D.C. 1970), rev'd, 445 F.2d 726 (D.C. Cir. 1971).

85 In one case, for example, the determination of responsiveness on a bid for equipment for an Atomic Energy Commission plant necessitated deciding whether offering transformers with top-mounted bushings and no terminal boxes was materially nonconforming to an invitation that specified sidewall bushings enclosed in terminal boxes. 38 COMP. GEN. 59, 61 (1958).

86 E.g., Allen M. Campbell Co. v. Lloyd Wood Constr. Co., 446 F.2d 261 (5th Cir. 1971); A.G. Schoonmaker Co. v. Resor, 445 F.2d 726 (D.C. Cir. 1971); M. Steinthal \& Co. v. Seamans, 455 F.2d 1289 (D.C. Cir. 1970).

87 Allen M. Campbell Co. v. Lloyd Wood Constr. Co., 446 F.2d 261 (5th Cir. 1971), upheld a determination of small business status by the SBA, stating that technical expertise was involved and deference would be given to the agency decision. In A.G. Schoonmaker Co. v. Resor, 445 F.2d 726 (D.C. Cir. 1971), and M. Steinthal \& Co. v. Seamans, 455 F.2d 1289 (D.C. Cir. 1970), the court, using a rational basis test, sustained findings by the Comptroller General that the invitations were ambiguous and readvertisement was necessary. Lombard Corp. v. Resor, 321 F. Supp. 687 (D.D.C. 1970), upheld a decision by the Comptroller General that the low bid was nonresponsive. 
protest cases have, with one exception, been approved by the district courts. ${ }^{88}$ The appropriateness of a limited scope of review has been premised, in particular, on the experience and expertise of the GAO, ${ }^{89}$ even though the great majority of the GAO's decisions, perhaps as a result of its limited function, have been in the government's favor ${ }^{90}$

In addition to the pressures toward limited review exerted by the greater competence of prior decision makers in evaluating bid protests, the courts have been concerned with the effects of judicial review on the ability of the government to procure goods and services expeditiously. In several cases, courts have justified affording only limited review on the ground that review delays final award of contracts, postpones delivery of goods and services, and defers the completion of necessary government projects. ${ }^{91}$ The effects of delay and the degree to which completion of a government project is vital to the public interest varies, of course, from case to case. In most cases concerning judicial review of administrative action, the public interest involved in a government program can, to some extent, be measured by the degree of discretionary authority vested by Congress in the officials charged with its operation. ${ }^{92}$ Procurement statutes, however, grant the same discretionary authority to contracting officers with respect to all procurements, however trivial or important they may be. ${ }^{93}$ Courts have, therefore, used a

88 Simpson Elec. Co. v. Seamans, 317 F. Supp. 684 (D.D.C. 1970), found, contrary to the Comptroller General's decision, that a telegraphed bid modification would have been received before the announced time for opening bids but for mishandling by government officials and, therefore, was not "late" within the meaning of procurement regulations.

89 Judge Levanthal, writing for the majority in M. Steinthal \& Co. v. Seamans, 455 F.2d 1289, 1304-05 (D.C. Cir. 1970), and in Wheelabrator Corp. v. Chafee, 455 F.2d 1306, 131317 (D.C. Cir. 1971), stated emphatically that courts should give great weight to decisions of the GAO, which has fifty years of experience in deciding bid protests, and should generally refrain from making a judicial determination of the controversy while a protest is pending with the GAO.

90 See note 51 supra. By upholding GAO determinations, recognizing that they are seldom favorable to the bidder, courts may be presenting bidders a dilemma: bidders may protest to the GAO, which is quicker and less expensive than litigation, Wheelabrator Corp. v. Chafee, 455 F.2d 1306, 1315 (D.C. Cir. 1971); but the GAO decision, which is not likely to remedy the bidder's grievance, will probably prevent a contrary judicial determination.

91 E.g., M. Steinthal \& Co. v. Seamans, 455 F.2d 1289 (D.C. Cix. 1970); City Chem. Corp. v. Shreffler, 333 F. Supp. 46 (S.D.N.Y. 1971).

92 Cf. K.C. Davis, supra note 75, § 30.10 .

93 One exception to this similar treatment of procurements which is of different importance is the agency's flexibility to negotiate where, because, for example, of urgent need, advertising is not feasible. 10 U.S.C. § 2304(a) (1970); 41 U.S.C. § 252(c) (1970). While some determinations are left to agency discretion, such as determining responsibility, 41 C.F.R. § I-I.I204(a) (1972), and other determinations are prescribed explicitly by regulations, for example, the manner of bid solicitation, 32 C.F.R. $\$ \S 2.200-2.211$ (1972); 41 C.F.R. $\S \S 1-2.201$ to $-2.208(1972)$, the precise extent of a contracting officer's general dis- 
common-sense approach to assessing the public interest in avoiding delay in procurement, allowing, for example, delay in contracting for ballpoint pens ${ }^{94}$ but not for materials used to control radioactivity. ${ }^{95}$ Courts have, in all cases, refused to delay procurements for national defense, which have been the subject of a majority of bidders' suits. ${ }^{96}$

The problem of delay in government procurement has influenced, in particular, the courts' decisions as to whether injunctive relief is appropriate. In most bid suits, bidders have sought preliminary injunctions delaying contract awards or performance. Although the issues of scope of review and the appropriateness of injunctive relief are analytically distinct, both determinations require consideration of the same interests. Perhaps because of this, the courts have often discussed the two questions simultaneously. ${ }^{97}$ Among the factors courts consider in deciding whether to grant a preliminary injunction are the probable harm that an injunction would cause the defendant, the harm that denial of an injunction would cause the plaintiff, and the effects of injunctive relief on public interests. ${ }^{98}$ The usual defendant in a bid

cretionary authority is unclear. Cf. Hanes \& S.B. Smith, The Contracting Officer: His Authority to Act and Duty to Act Independently, 70 Drck. L. REv. 333 (1966); McIntire, Authority of Government Contracting Officers: Estoppel and Apparent Authority, 25 Geo. WASH. L. REv. 162 (1951); Whelan \& Dunigan, Government Contracts: Apparent Authority and Estoppel, 55 GEO. L.J. 830 (1967); Note, Government Contracts: The Consequences of an Improper Award, 11 WM. \& MARY L. REV. 706 (1970).

94 Ballerina Pen Co. v. Kunzig, 433 F.2d 1204 (D.C. Cir. 1970), allowing suit for a mandatory injunction to require advertised bidding and withdrawal of a General Services Administration letter of commitment to the National Industries for the Blind agreeing to purchase pens from them.

${ }^{95}$ City Chem. Corp. v. Shreffler, 333 F. Supp. 46 (S.D.N.Y. 1971), denying relief to a disappointed bidder who asserted that the successful bidder was not a "manufacturer" of the items to be procured as required by the Walsh-Healy Act, $4 I$ U.S.C. $\$ \S 35-45$ (1970). The Walsh-Healy Act specifically provides for judicial review of administrative interpretations of the term "manufacturer," 4l U.S.C. $\$ 43 a$ (1970), but the district court in City Chemical held that, at least in the circumstances of that case, any reasonable interpretation of that term would be sustained.

96 A.G. Schoonmaker Co. v. Resor, 445 F.2d 726 (D.C. Cir. 1971) (generator sets for the Army); M. Steinthal \& Co. v. Seamans, 455 F.2d 1289 (D.C. Cir. 1970) (parachutes for the Air Force); City Chem. Corp. v. Shreffler, 333 F. Supp. 46 (S.D.N.Y. 1971) (chemicals to control radioactivity for the Navy); American Standard, Inc. v. Laird, 326 F. Supp. 492 (D.D.C. 1971) (advanced instrument landing systems for the Air Force); Lombard Corp. v. Resor, 321 F. Supp. 687 (D.D.C. 1970) (forging press lines to produce ammunition for the Army).

97 See, e.g., M. Steinthal \& Co. v. Seamans, 455 F.2d 1289 (D.C. Cir. 1970).

98 See, e.g., Delaware \& Hudson Ry. Co. v. United Transp. Union, 450 F.2d 608, 619 (D.C. Cir. 1971). Two other factors generally considered in granting or denying preliminary injunctions are the probability of the plaintiff's success and the injunction's effect on the status quo. The status quo would be preserved in virtually all bid cases by granting the preliminary injunction, which usually asks to have the contract award or performance stayed. Probability of success turns, in part, on the scope of review to be used: 
protest suit is the head of the procuring agency and, where a contract has been awarded prior to the initiation of the suit, the successful bidder. ${ }^{92}$ A preliminary injunction delaying procurement would, of course, delay the government program for which the procurement is proposed to be made. In addition to the harm to the government and the public that may result from delaying necessary procurements, courts have also been concerned with the harm that may result to the successful bidder because of a preliminary injunction and uncertainty as to the outcome of the suit. ${ }^{100}$ If the injunction is granted, the contractor may incur substantial costs in maintaining the workers and equipment necessary to perform the contract and may have difficulty in procuring other contracts pending the court's final decision.

Against these interests of the government and contractors opposing delay in contract awards or performance, courts must consider the harm to the protesting bidder that may result from denial of a preliminary injunction. If a preliminary injunction has been denied, the bidder who can prove his claim will, in all likelihood, not be entitled to a final injunction awarding the contract to him since the factors that prevent granting the preliminary injunction-the costs of delaymilitate at least as much against compelling transfer of the contract once work on it has begun.

Denial of a preliminary, or final, injunction would weigh much less harshly against the disappointed bidder if there were available to him a damage remedy for denial of a contract in violation of procurement laws. Federal district courts may not, however, award more than $\$ 10,000$ in damages in suits brought against the federal government; ${ }^{101}$ only the Court of Claims, which has limited awards in bidders'

the broader the scope of review, the greater the plaintiff's chance of success. Considering probability of success in these cases would lead courts in a circle insofar as it depends on the scope of review to be used, since the scope of review may be changed by the decision on injunctive relief. See text at notes 109-10 infra.

99 E.g., Allen M. Campbell Co. v. Lloyd Wood Constr. Co., 446 F.2d 261 (5th Cir. 1971). Even where the contractor is not a formal party to the dispute, if a recipient of the contract award has been designated, courts should recognize the effect of injunctive relief on his interests.

100 The uncertainty for the contractor depends on the remedy ultimately available to a successful protester. An injunctive remedy renders the contract uncertain, while a damage remedy does not affect the contractor. Several courts have expressed a preference for awarding damages as opposed to injunctions in bid cases. See M. Steinthal \& Co. v. Seamans, 455 F.2d 1289, 1302-03 (D.C. Cir. 1970); City Chem. Corp. v. Shreffler, 333 F. Supp. 46, 48 (S.D.N.Y. 1971); Simpson Elec. Co. v. Seamans, 317 F. Supp. 684, 687-88 (D.D.C. 1970). However, the damage remedy already provided in a limited group of cases has yet to be granted. See text and note at note 55 supra.

10128 U.S.G. §§ 1346, 1491 (1970). 
suits to bid preparation expenses, ${ }^{102}$ may award damages greater than this amount. ${ }^{103}$ Since bid preparation expenses often amount to several times $\$ 10,000,{ }^{104}$ bidders can recover them fully only in the Court of Claims. At the same time, however, these expenses account for only a small proportion of the damages the bidder has incurred since he will also have lost the profits that he could reasonably have expected to gain had he received the contract award. ${ }^{105}$ Despite this absence of a full damage remedy, the courts have generally held the disappointed bidder's interests outweighed by the necessity of avoiding delays in procurement. Since Scanwell, few preliminary injunctions have been granted; and in the few cases in which district courts have granted injunctions, the courts of appeals have reversed.08

\section{Relief for Bidders: The Role of the Court of Clatms}

Recent cases continue to cite Scanwell for the proposition that disappointed bidders, as representatives of their own interests and of the public's interest in fairness, have standing to bring actions for judicial review of their claims that agency actions violating procurement statutes and regulations have deprived them of contract awards. ${ }^{107}$ Yet the same

102 Keco Indus., Inc. v. United States, 428 F.2d 1233 (Ct. CI. 1970); Feyer Prods. Co. v. United States, 140 F. Supp. 409 (Ct. Cl. 1956).

10328 U.S.C. \$\$ 1346, 1491 (1970).

104 For example, in Robert F. Simmons \& Assocs. v. United States, 360 F.2d 962 (Ct. Cl. 1966), the plaintiff spent $\$ 23,028.73$ in bid preparation.

105 These lost profits are likely to be the major damage to the plaintiff; logically, a bidder would not spend nearly so much in preparing his bid as he would stand to make from the contract if he were to gain the award. The large face amounts of many contracts, for example, $\$ 32$ million for the contract contested in M. Steinthal \& Co. v. Seamans, 455 F.2d 1289 (D.C. Cir. 1970), also suggest substantial expected profits.

108 A.G. Schoonmaker Co. v. Resor, 319 F. Supp. 933 (D.D.C. 1970), rev'd, 445 F.2d 726 (D.C. Cir. 1971); M. Steinthal \& Co. v. Seamans, Civil No. $2422-70$ (D.D.C. Sept 3, 1970), rev'd, 455 F.2d 1289 (D.C. Cir. 1970); Wheelabrator Corp. v. Chafee, 319 F. Supp. 87 (D.D.C. 1970), rev'd, 455 F.2d 1306 (D.C. Cir. 1971); Lloyd Wood Constr. Co. v. Sandoval, 318 F. Supp. 1167 (N.D. Ala. 1970), rev'd sub nom., Allen M. Campbell Co. v. Lloyd Wood Constr. Co., 446 F.2d 261 (5th Cir. 1971). An injunction was issued in General Elec. Co. v. Seamans, 340 F. Supp. 636 (D.D.C. 1972) designed not to delay contract award, but to prevent action by one company (Philco) that would inhibit the plaintiff-company (General Electric) from effectively performing the contract if, as the court found likely, its protest to the GAO was successful. The contract in that case was for operation of Air Force tracking stations, and the injunction restrained Philco, to whom the contract was awarded by the agency, from contracting with the personnel presently operating the stations to prevent the employees' availability to General Electric.

107 A.G. Schoonmaker Co. v. Resor, 445 F.2d 726 (D.C. Cir. 1971); M. Steinthal \& Co. v. Seamans, 455 F.2d 1289 (D.C. Cir. 1970); City Chem. Corp. v. Shreffer, 333 F. Supp. 46 (S.D.N.Y. 1971); American Standard, Inc. v. Laird, 326 F. Supp. 492 (D.D.C. 1971); Lombard Corp. v. Resor, 321 F. Supp. 687 (D.D.C. 1970); Keco Indus., Inc. v. United States, 428 F.2d 1233 (Ct. Cl. 1970). 
decisions have effectively cut off judicial review of bid protests. The disappointed bidder has generally been unable to obtain independent review of the legality of contract awards, to secure an injunction delaying award of or work under a contract, or to gain compensation for lost profits from a wrongfully denied contract. This subordination of the bidder's and the public's interests in fairness to the demands of efficient government operations may not, however, be necessary. The Court of Claims, by affording a fully compensatory damage remedy, could at once protect the interests of bidders and, at the same time, avoid the inefficiencies that have frequently been cited as justifying limited review.

The Court of Claims has, without giving the matter much space in its opinions, generally followed the decisions of the district courts and courts of appeals in limiting the scope of review appropriate to bidders' suits. ${ }^{108}$ Many of the factors that militate against broad review of contract awards in suits brought in the district courts would, however, lose much of their force if the Court of Claims were to become the predominant forum for litigation of bid disputes. First, it may often be necessary for district courts to deny preliminary injunctions delaying contract awards in order to avoid impairing vital government projects. ${ }^{109}$ This general refusal to grant injunctions removes one of the justifications for limited judicial review since, if procurement is not postponed by injunction, review need not be limited in order to minimize delay. Because the Court of Claims cannot, in any case, afford injunctive relief, the problem of delay cannot serve to justify a limited scope of review. Second, the courts have, as noted above, often cited their relative inexpertness in procurement matters as reason for limiting review. If, however, the Court of Claims were to become the primary judicial forum for bid protests, it would be in a position to acquire considerable expertise concerning government bidding and could review at least nondiscretionary agency decisions involved in contract awards for their correctness rather than merely their rationality. ${ }^{110}$

Because of their consistent refusal to grant injunctions and because of the statutory limit on the amount of damages they can assess, ${ }^{111}$ the

108 See, e.g., Albano Cleaners, Inc. v. United States, 455 F.2d 556, 559-60 (Ct. Cl. 1972); Keco Indus., Inc. v. United States, 428 F.2d 1233, 1240 (Ct. Cl. 1970).

109 M. Steinthal \& Co. v. Seamans, 455 F.2d 1289, 1302-03 (D.C. Cir. 1970); City Chem. Corp. v. Shreffler, 333 F. Supp. 46, 48 (S.D.N.Y. 1971); Simpson Elec. Co. v. Seamans, 317 F. Supp. 684, 687-88 (D.D.C. 1970).

110 The Court of Claims has already had an opportunity to acquire considerable expertise on government contracting through its jurisdiction over disputes and terminations under the Wunderlich Act. 28 U.S.C. § 1491 (1970); U.S. Cr. CL. R. 161 et seq.

111 See text and notes at notes 101-03 supra. 
district and appellate courts have made the Court of Claims the logical forum for the litigation of bidders' complaints. Despite the unavailability of injunctive relief, however, the Court of Claims has refused to afford to disappointed bidders an effective remedy in damages. Neither in Heyer Products ${ }^{112}$ nor in Keco Industries ${ }^{113}$ did the Court of Claims explain why bid preparation expenses alone should be awarded to bidders able to demonstrate that they had been deprived of contracts by noncompliance with or misapplication of federal procurement laws. In Heyer Products, the court held that an invitation for bids constitutes an implied contract that all bids will be fairly considered, and that, if an invitation is made in bad faith, bidders who have relied upon it can recover. In Keco Industries, the court extended this implied contract theory to cases not involving bad faith invitation, holding, in effect, that the invitation constitutes an implied contract that the procuring agency will consider bids in accordance with all applicable statutes and regulations. The court should distinguish between two classes of disappointed bidders. Bidders who have relied upon the implied contract contained in a bid invitation but who would not have received the contract award even if the procuring agency had acted in good faith and complied with procurement law should be entitled to recover bid preparation expenses. But a bidder who would have received the award had the implied contract of good faith and compliance not been breached should be entitled to more: the profits he could reasonably have expected to derive if he had been awarded the procurement contract. ${ }^{114}$

112140 F. Supp. 409 (Ct. Cl. 1956).

113428 F.2d 1233 (Ct. G. 1970).

114 The contract that the Court of Claims has found implied in the invitation of bids and promulgation of regulations ostensibly controlling contract award is arguably analogous to a sales contract with the bidder in the role of seller. Under the UNIFORM ComMERCIAI CODE § 2-708(2) (1972 version), the seller would be entitled to his lost profits. The general theory in contract law is that damages protect the expectation interest, that is, they provide the party injured by breach with the equivalent of contract performance. E.g., Hadley v. Baxendale, 9 Ex. 341, 156 Eng. Rep. 145 (1854). But see Fuller \& Perdue, The Reliance Interest in Contract Damages, 46 YALE L.J. 52, 373 (1936). Cases refusing to give a party injured by breach of contract the profits lost as a result of the breach are an exception to this general rule. Most of these cases are distinguishable from the situation faced in government contracting in that the profits lost in those cases were generally speculative, to have been earned over an indefinite number of years and without reasonably reliable data to indicate their amount. See Goodman v. Dicker, 169 F.2d 684 (D.C. Cir. 1948); Hoffman v. Red Owl Stores, 26 Wis. 2d 683, 133 N.W.2d 267 (1965). Loss of a government contract generally deprives the bidder of a reasonably ascertainable amount to be earned over a short time. Thus, even if one accepts the hypothesis of the Court of Claims-that damages are given to the disappointed for breach of an implied contract-the damages given should include lost profits. There is, however, a more plausible basis for damages that militates more strongly in favor of awarding lost profits. 
The Court of Claims has remained silent as to its reason for limiting damage awards to bid preparation expenses whether or not the bidder should have been awarded the contract. It has been suggested, however, that this refusal to award expected profits is justified because, in certain circumstances, the government, unlike a private party to a contract, often has authority to terminate a contract after it has been awarded, thus depriving a contractor of his prospective profits. ${ }^{115}$ While the government's right to terminate should perhaps be a factor in determining what profits a bidder could reasonably have expected, ${ }^{116}$ it does not justify excluding lost profits entirely from the bidder's damage award. ${ }^{117}$ Since the government can only terminate under certain condi-

Damage remedies for breach of contract give the contracting parties flexibility while holding them within their intended bargain. See O. HolmEs, ELEMENTS of ConTract IN THE COMMON LAW 235-36 (M. Howe ed. 1963); J. StoRY, 2 EquTry JURISPRUdence 25 (1836). One party may find it more economical to breach the contract, knowing that he must pay the other party the amount that that party could reasonably have expected to receive through performance of the contract. This choice, rooted in the individual's assessment of his economic best interest, is allowed to the contracting individual to preserve his economic freedom while enforcing the spirit of his promise. But there is no analogous interest of the federal government in knowingly breaking its promise, at least where that promise is in the form of law. The contracting officer is directed by law to award contracts in a given fashion. One might argue that it would be more efficient to allow the contracting officer this choice, but Congress has stated that the interest in efficiency does not require that such discretion be given to administrative officers. To the extent that paying lost profits deters violations of law, it is warranted to enforce the statutes; furthermore, the party injured by breach of a promise, where allowing the breach advances a recognized interest (economic freedom of choice), should be no better off than the party injured by a violation of law that advances no interest.

115 M. Steinthal \& Co. v. Seamans, 455 F.2d 1289, 1304 (D.C. Cir. 1970).

116 The court could determine the percentage of contracts, or of contracts of a particular type, that are cancelled and reduce the bidder's recovery by that percentage, or courts could devise any number of other formulae to allow for the possibility of "termination for the government's convenience."

117 This refusal of the Court of Claims to grant loss profits seems inconsistent with the result reached in Allen M. Campbell Co. v. United States, No. 397-70 (Ct. Cl., Oct. 13, 1972). In this case the Court of Claims granted standard damages for termination, including some lost profits, to a bidder whose contract award had been rescinded after a district court held that the bidder was not a small business as required for the contract at issue. Lloyd Wood Constr. Co. v. Sandoval, 318 F. Supp. 1167 (N.D. Ala. 1970). Campbell, the bidder losing in the district court, appealed to the Fifth Circuit, which reversed the district court's decision and held the rescission and award to the next low bidder, Wood, improper. The Court of Appeals failed, however, to grant relief since Wood had nearly completed the contract work. Allen M. Campbell Co. v. Lloyd Wood Constr. Co., 446 F.2d 261 (5th Cir. 1971). In granting termination-of-contract damages to Campbell, the Court of Claims relied on an earlier ruling that a Small Business Administration determination of small business status is conclusive, so that even if Campbell did not meet the statutory test for small business status, it could not be denied the contract on that ground. MidWest Constr., Ltd. v. United States, 387 F.2d 957 (Ct. Cl. 1967). Rescission of a contract not awarded in accordance with statutory criteria, other than for small business status, or improper denial of a contract on other grounds would, under the Keco rule, have precluded the grant of any damages for lost profits. 
tions, it is no answer to the bidder's claim to lost profits that, even if he had been awarded the contract, he would not have received the profits had those conditions occurred.

\section{SUMMARY}

Although federal courts have recognized that bidders for government contracts and the public have an interest in having contracts awarded according to the requirements of the applicable statutes and regulations, decisions since Scanwell have refused to protect these interests because of conflicting interests in governmental efficiency. Judicial deference to decisions of administrative agencies, particularly the GAO, has deprived the protesting bidder of an independent determination of the meaning of procurement statutes and regulations as applied to his case. By limiting the scope of review, the courts have subordinated enforcement of procurement laws to the efficient operation of the government.

Federal district and appellate courts have generally considered the scope of review of agency contract decisions together with the propriety of granting injunctions delaying contract awards. Emphasizing the greater competence of administrative decision makers and the need to avoid interfering with important government functions, courts have announced a limited scope of review and denied injunctions delaying contract awards. By severely limiting the availability of injunctive relief, the district and appellate courts have made the Court of Claims the logical forum for bid suits, thereby enabling one court to acquire competence in bid matters. Because it can grant only damage remedies, the Court of Claims need not be concerned with the problem of delaying contract awards; it should, therefore, recognize that the factors that support limited review by the district courts of agency contract decisions do not necessarily justify the same limitations on the review that it affords. The Court of Claims should, in addition, expand the available damage remedy to compensate bidders fully for the loss they have incurred because of administrative failure to comply with procurement laws. By doing so, the court could afford an effective remedy for bidders and thus help to maintain the integrity of the government procurement process. 